\title{
Bioremediation of Waters Contaminated with Heavy Metals Using Moringa oleifera Seeds as Biosorbent
}

\author{
Cleide S. T. Araújo, Dayene C. Carvalho, \\ Helen C. Rezende, Ione L. S. Almeida, \\ Luciana M. Coelho, Nívia M. M. Coelho, \\ Thiago L. Marques and Vanessa N. Alves \\ Additional information is available at the end of the chapter \\ http://dx.doi.org/10.5772/56157
}

\section{Introduction}

Water is not only a resource, it is a life source. It is well established that water is important for life. Water is useful for several purposes including agricultural, industrial, household, recreational and environmental activities. Despite its extensive use, in most parts of the world water is a scarce resource. Ninety percent of the water on earth is seawater in the oceans, only three percent is fresh water and just over two thirds of this is frozen in glaciers and polar ice caps. The remaining unfrozen freshwater is found mainly as groundwater, with only a small fraction present above ground or in the air. Thus, almost all of the fresh water that is available for human use is either contained in soils and rocks below the surface, called groundwater, or in rivers and lakes.

The contamination of soil and water resources with environmentally harmful chemicals represents a problem of great concern not only in relation to the biota in the receiving environment, but also to humans. The continuing growth in industrialization and urbanization has led to the natural environment being exposed to ever increasing levels of toxic elements, such as heavy metals. Approximately $10 \%$ of the wastes produced by developed countries contain heavy metals. Figure 1 gives some indication of the amounts of metal-containing waste produced in developed countries. Much of the discharge of metals to the environment comes from mining, followed by agriculture activities. 


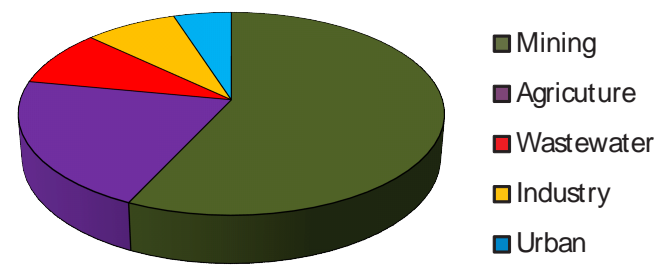

Figure 1. Waste containing heavy metals produced in developed countries [1].

Many different definitions have been proposed for heavy metals, some based on density, some on atomic number or atomic weight, and others on chemical properties or toxicity, which are not necessarily appropriate. For example, cobalt, iron, copper, manganese, molybdenium, vanadium, strontium and zinc are required to perform vital functions in the body and therefore cannot be considered as compounds with high toxicity or ecotoxic properties. Regarding the meaning of the term "heavy metal" it was found that there can be misinterpretation due to the contradictory definitions and lack of a coherent scientific basis [2].

In conventional usage "heavy" implies high density and "metal" refers to the pure element or an alloy of metallic elements. According to Duffus [2], a new classification should reflect our understanding of the chemical basis of toxicity and allow toxic effects to be predicted. Various publications have used the term "heavy metals" related to chemical hazards and this definition will also be used herein. Among the classes of contaminants, heavy metals deserve greater concern because of their high toxicity, accumulation and retention in the human body. Moreover, heavy metals do not degrade to harmless end products [3, 4]. It is well established that the presence of heavy metals in the environment, even in moderate concentrations, is responsible for producing a variety of illnesses of the central nervous system (manganese, mercury, lead, arsenic), the kidneys or liver (mercury, lead, cadmium, copper) and skin, bones, or teeth (nickel, cadmium, copper, chromium) [5].

Due to its properties, water is particularly vulnerable to contamination with heavy metals. Table 1 shows the maximum limits for some metals in drinking water, according to the US Environmental Protection Agency (US EPA) [6]. The US EPA requires that lead, cadmium and total chromium levels in drinking water do not to exceed $0.015,0.005$ and $0.1 \mathrm{mg} \mathrm{L}^{-1}$, respectively. Corresponding values for other metals are presented in Table 1.

Within this context, and considering that heavy metals do not decay and are toxic even at low concentrations, it is necessary to remove them from various types of water samples. Of the conventional treatments used for the removal of metals from liquid waste, chemical precipitation and ion exchange are the predominant methods. However, they have some limitations since they are uneconomical and do not completely remove metal ions, and thus new removal processes are required [7-9]. Table 2 illustrates in more detail the advantages and limitations of the traditional methods applied to treat effluents. 


\begin{tabular}{cc}
\hline Element & US EPA Limit $\left(\mathbf{m g ~ L}^{-1}\right)$ \\
\hline Antimony & 0.006 \\
\hline Arsenic & 0.010 \\
\hline Beryllium & 0.004 \\
\hline Chromium (total) & 0.1 \\
\hline Cadmium & 0.005 \\
\hline Cupper & 1.3 \\
\hline Lead & 0.015 \\
\hline Mercury & 0.002 \\
\hline Selenium & 0.05 \\
\hline Silver & 0.1 \\
\hline
\end{tabular}

Table 1. Maximum acceptable concentrations of metals in drinking water according to the US EPA [6].

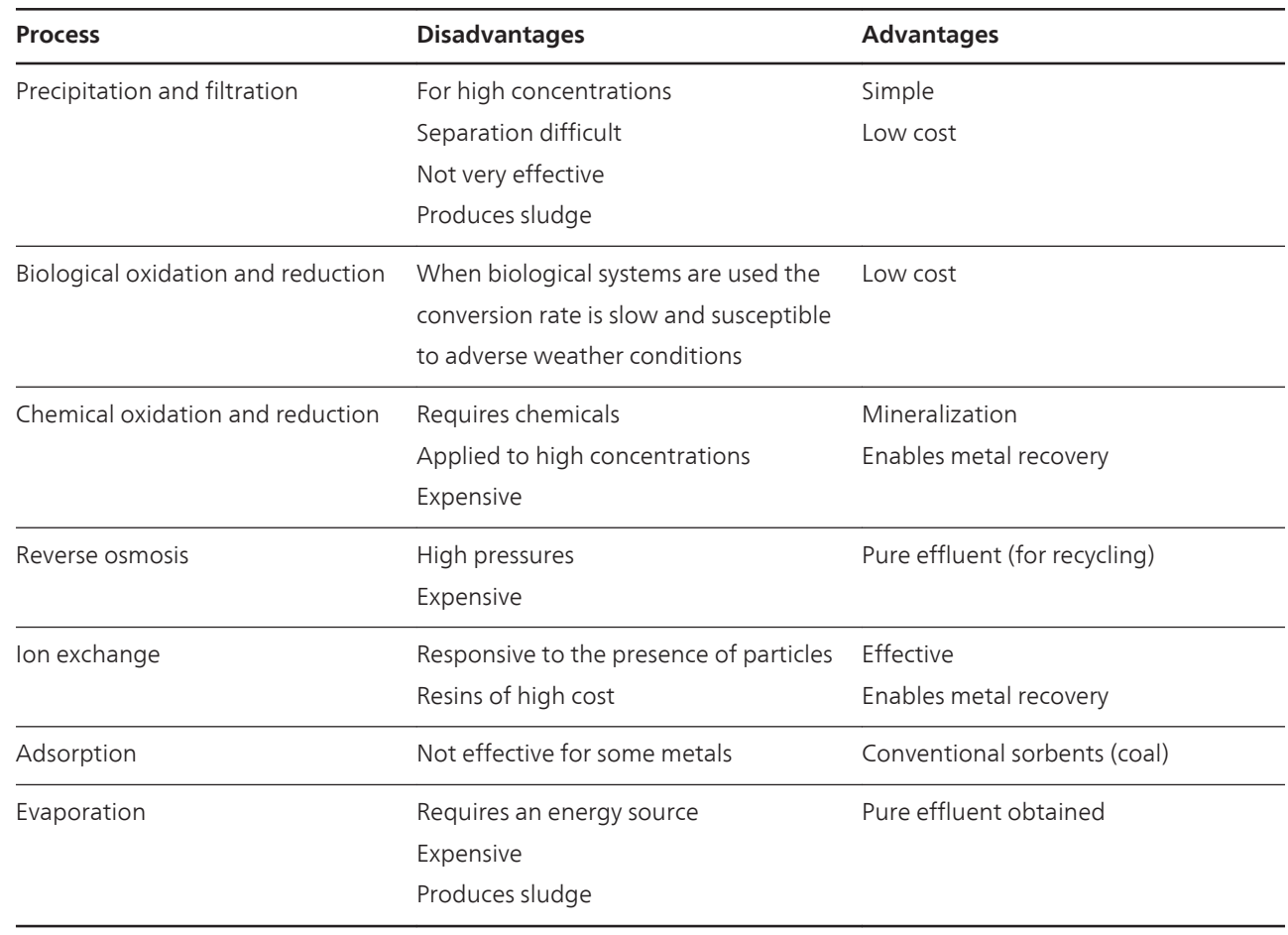

Table 2. Traditional process used in wastewater treatment: advantages and disadvantages [10]. 
For these reasons, alternative technologies that are practical, efficient and cost effective for low metal concentrations are being investigated. Biosorption in the removal of toxic heavy metals is especially suited as a 'nonpolluted ' wastewater treatment step because it can produce close to drinking water quality from initial metal concentrations of 1-100 $\mathrm{mg} \mathrm{L}^{-1}$, providing final concentrations of $<0.01-0.1 \mathrm{mg} \mathrm{L}^{-1}$ [11]. Biosorption has been defined as the ability of certain biomolecules or types of biomass to bind and concentrate selected ions or other molecules from aqueous solutions. It should to be distinguished from bioaccumulation which is based on active metabolic transport; biosorption by dead biomass is a passive process based mainly on the affinity between the biosorbent and the sorbate [12]. The biosorption of heavy metals by non-living biomass of plant origin is an innovative and alternative technology for the removal of these pollutants from aqueous solution and offers several advantages such as low-cost biosorbents, high efficiency, minimization of chemical and/or biological sludge, and regeneration of the biosorbent [13].

Recently, natural adsorbents have been proposed for removing metal ions due to their good adsorption capacity. Technologies based on the use of such materials offer a good alternative to conventional technologies for metal recovery. In this context, Moringa oleifera represents an alternative material for this purpose [14-16].

\section{Moringa oleifera}

Moringa oleifera is the best known species of the Moringaceae family. Moringaceae is a family of plants belonging to the order Brassicales. It is represented by fourteen species and a single genus (Moringa), being considered an angiosperm plant. It is a shrub or small tree which is fast growing, reaching 12 meters in height. It has an open crown and usually a single trunk (Figure 2). It grows mainly in the semi-arid tropics and subtropics. Since its preferred habitat is dry sandy soil, it tolerates poor soils, such as those in coastal areas [17].

Native to northern India, it currently grows in many regions including Africa, Arabia, Southeast Asia, the Pacific and Caribbean Islands and South America [3, 16, 19]. It is cultivated for its food, medicinal and culinary value and its leaves, fruits and roots are the parts used. It is commonly known as the 'horseradish' tree arising from the taste of a condiment prepared from the roots or 'drumstick' tree due to the shape of the pods. Figures 3 and 4 show the pods and seeds of this tree. M. oleifera has a host of other country-specific vernacular names, an indication of the significance of the tree around the world [16, 20-23].

Research has focused on the use of M. oleifera seeds and fruits in water purification and the treatment of turbid water is the best-known application. The seeds of various species contain cationic polyelectrolytes which have proved to be effective in the treatment of water, as a substitute for aluminum sulfate. Interest in the study of natural coagulants for water clarification is not new. The coagulant is obtained from a byproduct of oil extraction and the residue can be used as a fertilizer or processed for animal fodder. Compared to the commonly used 


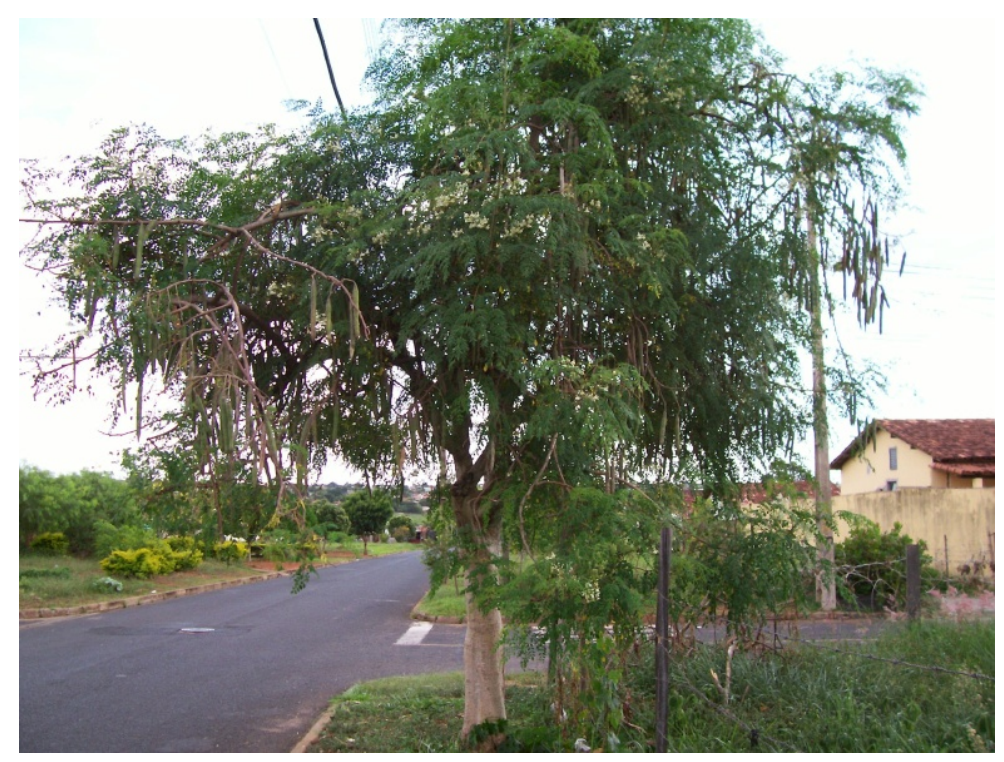

Figure 2. Tree of Moringa oleifera species [18].

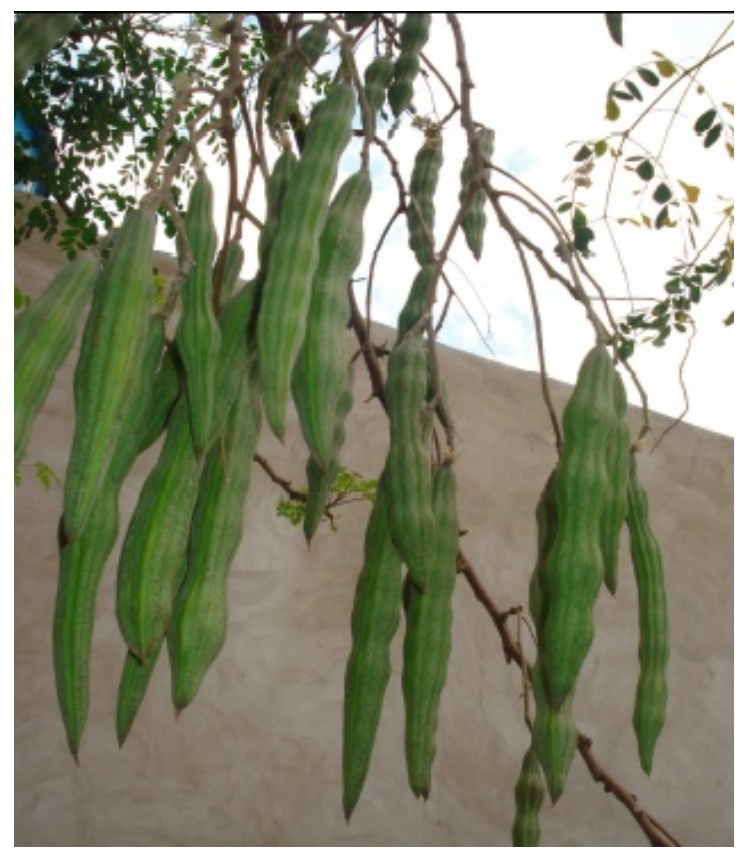

Figure 3. Pods of Moringa oleifera [18]. 


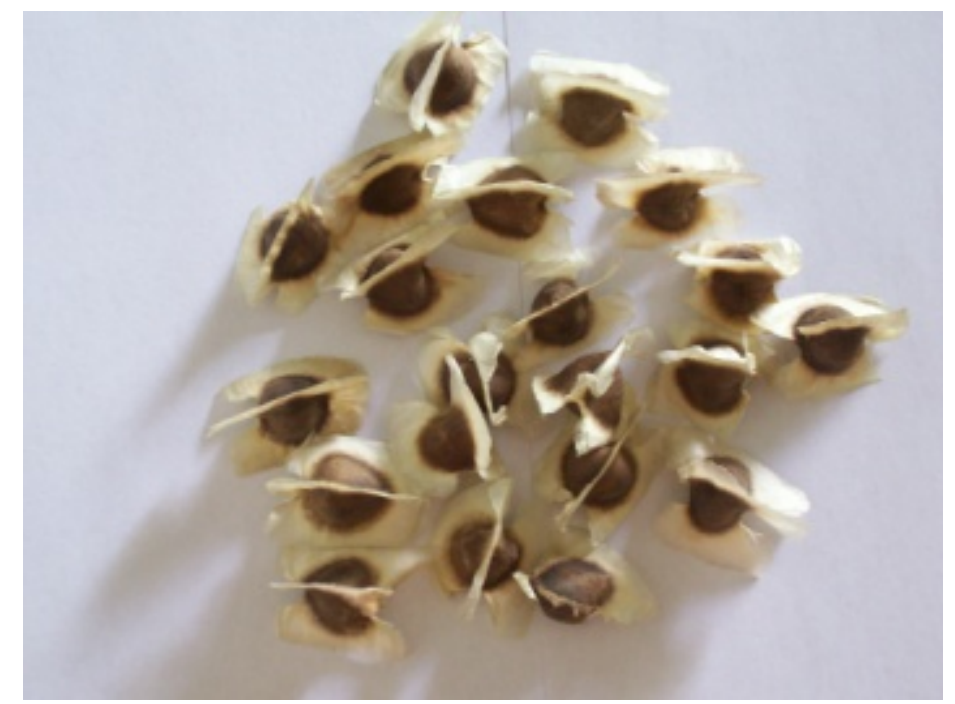

Figure 4. Seeds of Moringa oleifera [18].

coagulant chemicals, Moringa oleifera has a number of advantages including low cost, biodegradable sludge production and lower sludge volume, and also it does not affect the $\mathrm{pH}$ of the water. Apart from turbidity removal, M. oleifera seeds also possess antimicrobial properties $[24,25]$, although the mechanism by which seeds act upon microorganisms is not yet fully understood.

Tissues of M. oleifera from a wide variety of sources have been analyzed for glucosinolates and phenolics (flavonoids, anthocyanins, proanthocyanidins, and cinnamates). M. oleifera seeds reportedly contain 4-( $\alpha$-L-rhamnopyranosyloxy)-benzylglucosinolate in high concentrations. Roots of M. oleifera have high concentrations of both 4-( $\alpha$-L-rhamnopyranosyloxy)-benzylglucosinolate and benzyl glucosinolate. Leaves contain 4-( $\alpha$-L-rhamnopyranosyloxy)-benzylglucosinolate and three monoacetyl isomers of this glucosinolate and only 4- $(\alpha-\mathrm{L}-$ rhamnopyranosyloxy)-benzylglucosinolate has been detected in M. oleifera bark tissue [26]. Every glucosinolate contains a central carbon atom which is bonded to the thioglucose group (forming a sulfated ketoxime) via a sulfur atom and to a sulfate group via a nitrogen atom. These functional groups containing sulfur and nitrogen are good metal sequesters from aqueous solution. The leaves of $M$. oleifera reportedly contain quercetin-3-O-glucoside and quercetin-3-O-(6" '-malonyl-glucoside), and lower amounts of kaempferol-3-O-glucoside and kaempferol-3-O-(6" '-malonyl-glucoside), along with 3-caffeoylquinic acid and 5-caffeoylquinic acid. Neither proanthocyanidins nor anthocyanins have been detected in any of the tissues [26]. Although M. oleifera seeds have been most widely applied as a coagulant agent, many studies have been performed in order to explore other potential applications of this material, especially in the removal of metals from aqueous systems. 


\section{Biosorption of metals using Moringa oleifera}

Since Moringa oleifera seeds have the ability to retain metals, it is necessary to define and to understand the functional groups responsible for the adsorption phenomenon. Biosorption by dead biomass or by some molecules and/or their active groups is a passive process based mainly on the affinity between the biosorbent and the sorbate. In this case, the metal is sequestered by chemical sites naturally present in the biomass. The diagram in Figure 5 illustrates the main steps in this process. In most cases, the biosorption process is rapid and takes place under normal temperature and pressure. After the process of phase separation a biomass "charged" with metal ions and an effluent free of contamination are obtained. Two paths can be followed to deal with the "contaminated" biomass, the one of greatest interest being biosorbent regeneration and metal recovery. This process is the most attractive because biomass can be used for the removal of other metal species from other contaminated effluents. The other option is the destruction of the biomass, which offers no possibility of reuse.

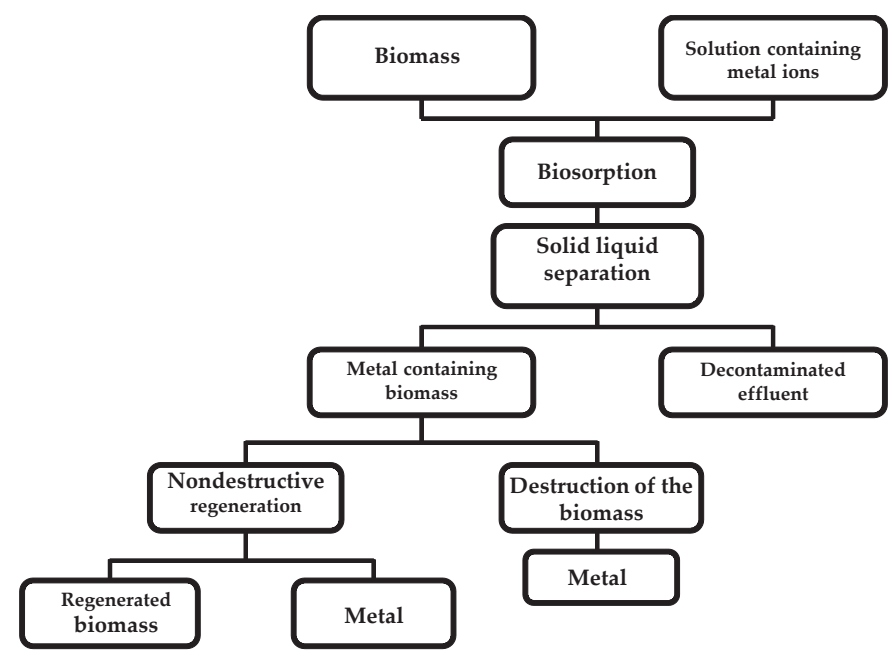

Figure 5. Main steps in biosorption process [27].

The mechanisms associated with heavy metal biosorption by biomass are still not clear; however, it is important to note that this process is not based on a single mechanism. Since metals may be present in the aquatic environment in dissolved or particulate forms, they can be dissolved as free hydrated ions or as complex ions chelated with inorganic ligands, such as hydroxide, chloride or carbonate, or they may be complexed with organic ligands such as amines, humic or fulvic acids and proteins. Metal sequestration occurs through complex mechanisms, including ion-exchange and complexation, and it is quite possible that at least some of these mechanisms act simultaneously to varying degrees depending on the biomass, the metal ion and the solution environment. 
In reference [28] indicated that ion-exchange is an important concept in biosorption, because it explains many of the observations made during heavy metal uptake experiments. In this context, the term ion-exchange does not explicitly identify the mechanism of heavy metal binding to biomass, and electrostatic or London-van der Waals forces should be considered as the precise mechanism of chemical binding, i.e., ionic and covalent bonds. Figure 6 provides a schematic representation of an ion-exchange mechanism for a biosorbent material where "Me" represents a metal with valence +2 .

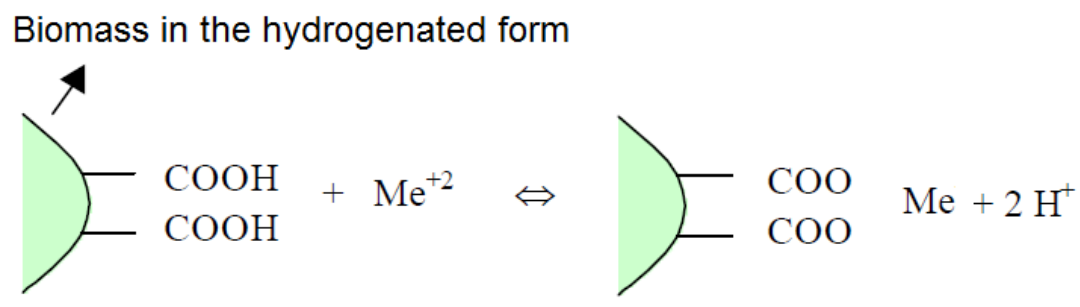

Figure 6. Schematic diagram of an ion exchange mechanism [29]

The seeds of Moringa oleifera and its parts can be classified as lignocellulosic adsorbents, consisting mainly of cellulose, hemicellulose and lignin. These functional groups are comprised of macromolecules that have the ability to absorb metal ions through ion exchange or complexation [30] phenomena which occur on the surface of the material through the interaction of the metal with the functional groups present. In order to understand the adsorption process it is also important to characterize the biomass material. Several techniques can be used to define the functional groups responsible for the adsorption phenomenon.

Infrared spectroscopy is an important technique in the qualitative analysis of organic compounds, widely used in the areas of natural products, organic synthesis and transformations. It is applied as a tool to elucidate the functional groups which may be present in substances [31], particularly with respect to the availability of the main groups involved in adsorption phenomena.

Figure 7 shows FT-IR spectra for Moringa oleifera seeds which verify the presence of many functional groups, indicating the complex nature of this material. The bandwidth centered at $3420 \mathrm{~cm}^{-1}$ may be attributed to the stretching of $\mathrm{OH}$ bonds present in proteins, fatty acids, carbohydrates and lignin units [32]. Due to the high content of protein present in the seed there is also a contribution in this region from N-H stretching of the amide bond. The peaks present at $2923 \mathrm{~cm}^{-1}$ and $2852 \mathrm{~cm}^{-1}$, respectively, correspond to asymmetric and symmetric stretching of the $\mathrm{C}-\mathrm{H}$ bond of the $\mathrm{CH}_{2}$ group. Due to the high intensity of these bands it is possible to assign them to the predominantly lipid component of the seed, which is present in a high proportion similar to that of protein [33]. In the region of $1800-1500 \mathrm{~cm}^{-1}$ a number of overlapping bands are observed and between 1750 and $1630 \mathrm{~cm}^{-1}$ this can be attributed to $\mathrm{C}=\mathrm{O}$ stretching. Due to the heterogeneous nature of the seed, the carbonyl group may be bonded to different neighborhoods as part of the fatty acids of the lipid portion or amides of the protein portion. The carbonyl 
component that appears due to the presence of lipids can be seen at 1740 and $1715 \mathrm{~cm}^{-1}$, as can be observed in the infrared spectra as small peaks, and the shoulders forming part of the main band that appears at $1658 \mathrm{~cm}^{-1}$ are attributed to the carbonyl amides present in the protein portion. The peak observed at $1587 \mathrm{~cm}^{-1}$ may be attributed to stretching connecting $\mathrm{CN}$ and also the deformation of the $\mathrm{N}-\mathrm{H}$ bond present in the proteins of seeds [34, 35].

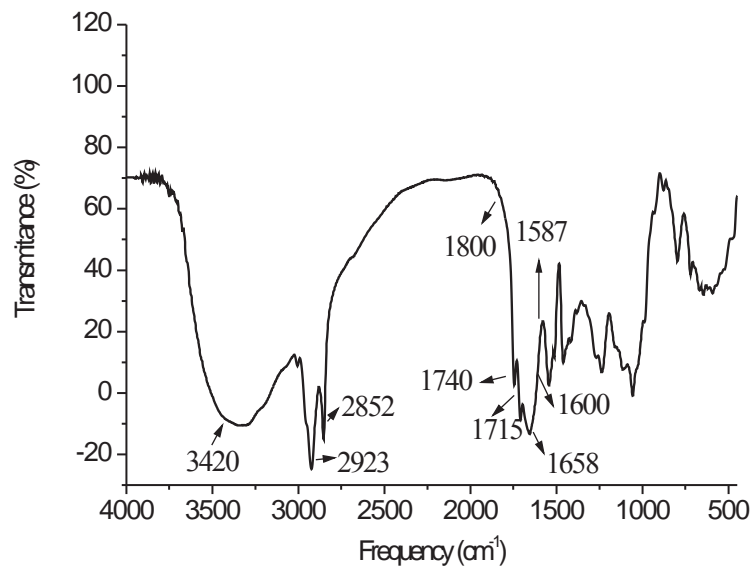

Figure 7. FT-IR spectrum of Moringa oleifera seeds. The arrows indicate the maximum signal obtained [36].

Among the various techniques for material characterization, the X-ray diffraction (XRD) technique is recommended for the evaluation of the presence of crystalline phases present in natural materials. In general, we can classify materials as amorphous, semicrystalline or crystalline. Figure 8 shows the XRD patterns for M. oleifera seeds. The XRD pattern for crushed seeds, due to the high amount of oils and proteins present in the composition of the material which represent around 69\% of the total mass [36], shows unresolved signals (predominantly amorphous). For this reason intact seeds are analyzed, constituting a complex matrix comprised of a wide variation of substances including proteins, lipid structures and, to a lesser extent, carbohydrates. It was possible to separate a broad peak at around $2 \theta$ equals $10^{\circ}$. The presence of this peak is probably associated with the diffraction of the protein constituent surrounded by other components which have a more amorphous pattern [37]. The amorphous nature of the biosorbent suggests that the metal ion could more easily penetrate the biosorbent surface.

Thermogravimetric (TG) analysis was used to characterize the decomposition stages and thermal stability determined through the mass loss of a substance subjected to a constant heating rate for a specified time. The mass loss curve for a sample of Moringa oleifera seeds can be observed in Figure 9, showing a typical profile that indicates several stages of the decomposition process. This thermogravimetric curve verifies the sample heterogeneity, since the intermediates formed are a mixture of several components. The mass loss curve can be divided into three stages: i) the first step occurs from $30^{\circ} \mathrm{C}$ to $128^{\circ} \mathrm{C}$ where a mass loss in the order of $8 \%$, associated with water desorption, was observed. The amount of water loss from seeds determined by this technique is similar to the value of $8.9 \%$ found in [38]; ii) in the second step 
$32 \%$ of mass loss was observed in the temperature range of $128-268^{\circ} \mathrm{C}$. This stage occurs due to the decomposition of organic matter, probably the protein component, present in seeds; and iii) the third step occurs from $268^{\circ} \mathrm{C}$ to $541^{\circ} \mathrm{C}$ with decomposition of the greater part of the seed components, which probably includes fatty acids, for example, oleic acid has a boiling point of $360^{\circ} \mathrm{C}$. At $950^{\circ} \mathrm{C}$ a total residue of around $14.6 \%$ was observed, due to the ash content and probably inorganic oxides.

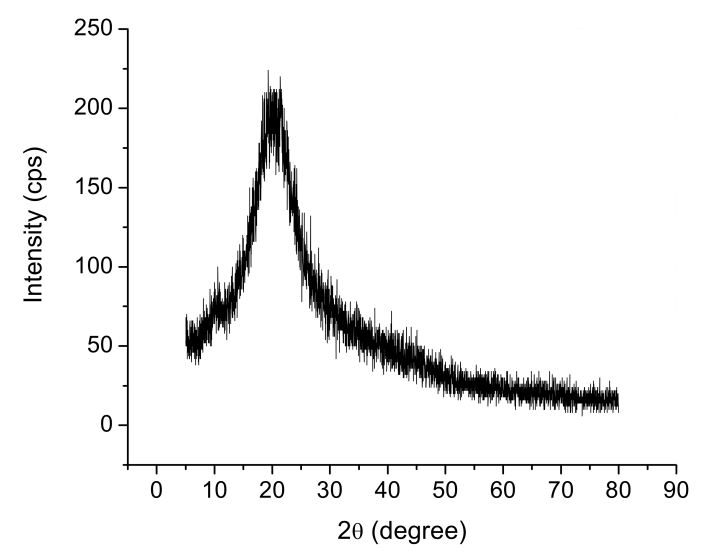

Figure 8. X-ray diffractogram for Moringa oleifera seeds [36].

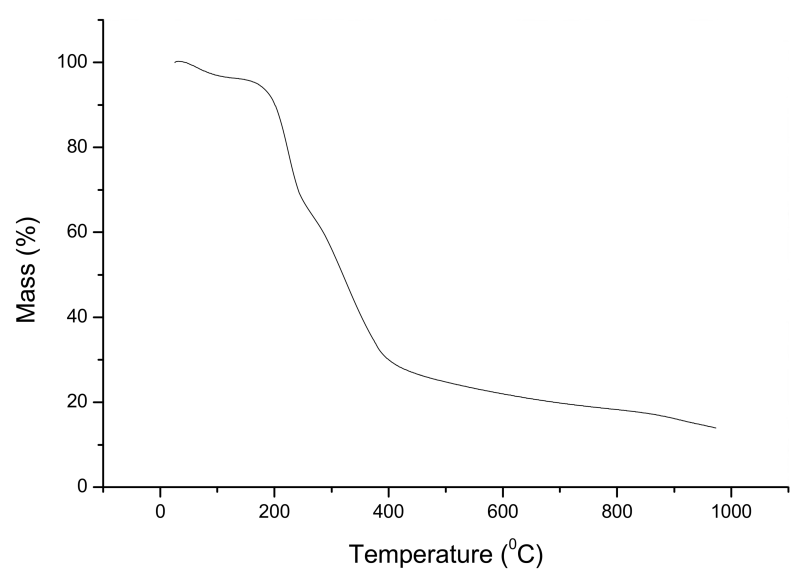

Figure 9. Thermogravimetric curve for Moringa oleifera seeds [36].

The morphological characteristics of the crushed seeds obtained using a scanning electron microscopy (SEM) can be seen in Figure 10. The results reveal that the material exhibits a relatively porous matrix with heterogeneous pore distribution. This feature is attributed to the fact that the whole seed comprises a wide variety of biomass components. The presence of 
some deformations on the surface of the plant tissue can be observed, containing available sites, from which it is possible to infer that the adsorbent provides favorable conditions for the adsorption of metal species in the interstices [35].

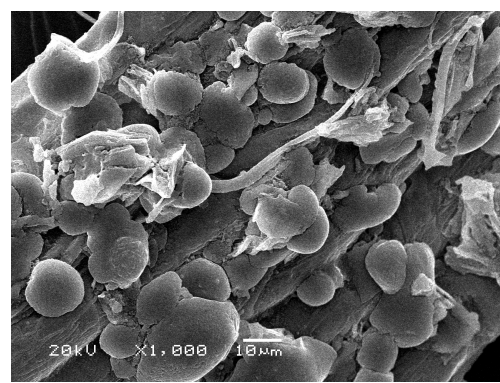

(a)

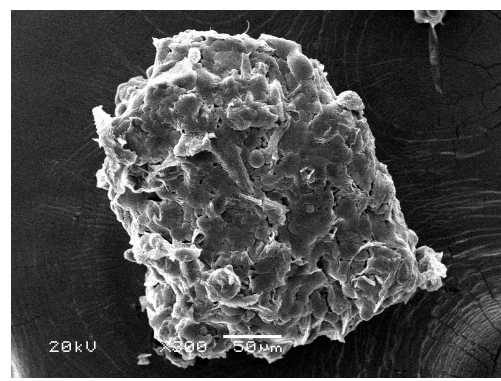

(b)

Figure 10. Scanning electron micrographs of Moringa oleifera. In the order of (a) $10 \mu \mathrm{m}$ and (b) $50 \mu \mathrm{m}$ [36].

\section{Influence of parameters in biosorption process}

Many variables can influence metal biosorption and experimental parameters such as temperature, stirring time, $\mathrm{pH}$, particle size of the biomass, ionic strength and competition between metal ions can have a significant effect on metal binding to biomass. The biomass mass also influences the adsorption process because as the adsorbent dose increases the number of adsorbent particles also increases and there is greater availability of sites for adsorption. Some of the most important factors affecting metal binding are discussed below. In general, adsorption experiments are carried out in batch mode.

The $\mathrm{pH}$ is one of the most important parameters affecting any adsorption process. This dependence is closely related to the acid-base properties of various functional groups on the adsorbent surfaces [39]. The literature shows that a heterogeneous aqueous mixture of $M$. oleifera seeds contains various functional groups, mainly amino and acids groups. These groups have the ability to interact with metal ions, depending on the $\mathrm{pH}$. An increase in metal adsorption with increasing $\mathrm{pH}$ values can be explained on the basis of competition between the proton and metal ions for the same functional groups, and a decrease in the positive surface charge, which results in a higher electrostatic attraction between the biosorbent surface and the metal [40]. Low $\mathrm{pH}$ conditions allow hydrogen and hydronium ions to compete with metal binding sites on the biomass, leading to poor uptake. Biosorbent materials primarily contain weak acidic and basic functional groups. It follows from the theory of acid-base equilibrium that, in the $\mathrm{pH}$ range of $2.5-5$, the binding of heavy metal cations is determined primarily by the dissociation state of the weak acidic groups. Carboxyl groups $(-\mathrm{COOH})$ are important groups for metal uptake by biological materials. At higher solution $\mathrm{pH}$, the solubility of a metal complex decreases sufficiently for its precipitation, leading to a reduced sorption capacity. 
Therefore, it is recommendable to study biosorption at $\mathrm{pH}$ values where precipitation does not occur. Biomasses are materials with an amphoteric character; thus, depending on the $\mathrm{pH}$ of the solution, their surfaces can be positively or negatively charged. At $\mathrm{pH}$ values greater than the point of zero discharge $\left(\mathrm{pH}_{p z c}\right)$, the biomass surface becomes negatively charged, favoring the adsorption of cationic species. However, adsorption of anionic species will be favored at $\mathrm{pH}<p H_{p z c}$. The $p H_{p z c}$ of the M. oleifera seeds is between 6.0 and 7.0 [41], indicating that the surface of the biosorbent presents acid characteristics. Figure 11 illustrates the surface charge or the point of zero net proton charge of Moringa oleifera seeds. The surface charge of the seeds is positive at $\mathrm{pH}<\mathrm{PZC}$, is neutral at $\mathrm{pH}=\mathrm{PZC}$ and is negative at $\mathrm{pH}>\mathrm{PZC}$. The variation in $\mathrm{pH}$ caused by protonation and deprotonation of the adsorbent reflects the presence of functional groups. Table 3 shows the use of components of the $\mathrm{M}$ oleifera in the $\mathrm{pH}$ range of 2.5 to 8.0 .

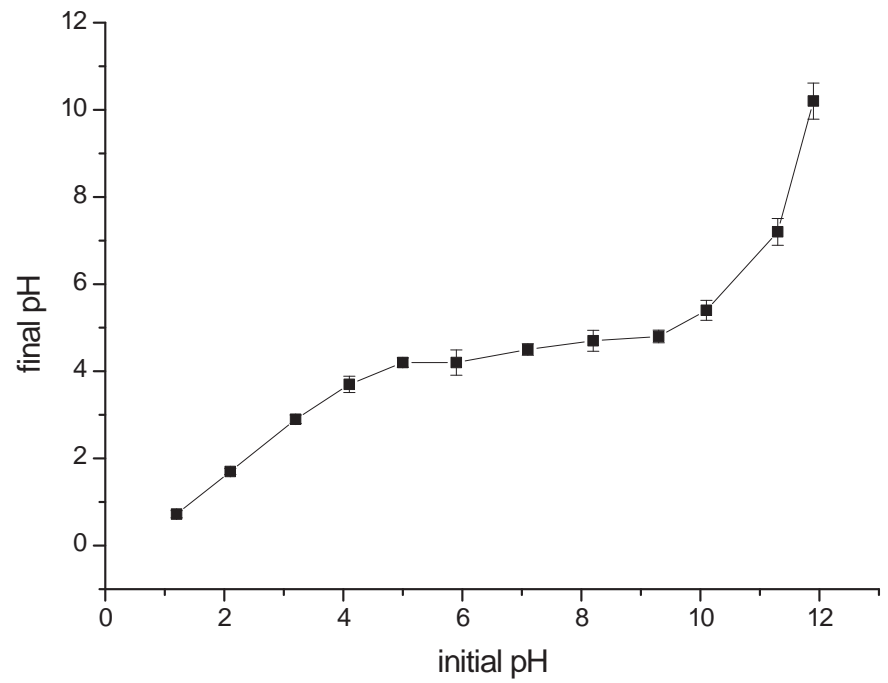

Figure 11. Point of zero net proton charge of Moringa oleifera seeds.

It has been noted that the temperature can influence the sorption process. Simple physical sorption processes are generally exothermic, i.e., the equilibrium constant decreases with increasing temperature. According to data reported in the literature (Table 3), the binding of the metal to different parts of the M. oleifera plant can be observed when the temperature is raised from 22 to $50{ }^{\circ} \mathrm{C}$.

The contact time (or stirring time) is another important parameter that influences the efficiency of the adsorption process. As can be seen in Table 3, a period of 5 min was chosen for the nickel sorption process and good results were obtained; however, longer times ( $240 \mathrm{~min}$ ) are required when using activated carbon. 
Moringa oleifera is capable of directly sorbing metal ionic species from aqueous solutions. An interesting characteristic assigned to these biosorbents is the high abrasive content and the relative chemical resistance, allowing them to be subjected to different chemical treatments to increase their affinity and/or specificity for metal ions. Results previously published show the potential use of untreated seeds, although biosorbent materials are generally derived from plant biomass through different kinds of simple procedures. They may be chemically pretreated for better performance and/or suitability for process applications. However, good results have been obtained when the seeds were treated with $\mathrm{NaOH}$. This treatment can remove organic and inorganic matter from the sorbent surface. Chemical treatments are commonly performed employing alkaline solutions or with phosphoric and citric acids [42]. Recently, however, efforts have been made to remove and subsequently also recover metals. Metal-saturated biosorbent materials can be easily regenerated applying a simple (e.g. acidic) wash which then contains a very high concentration of released metals in a small volume, making the solution quite amenable to metal recovery.

\begin{tabular}{|c|c|c|c|c|c|c|}
\hline Moringa Oleifera & Modifying agent(s) & Heavy metal & $\begin{array}{l}\text { Temperature } \\
\left({ }^{\circ} \mathrm{C}\right)\end{array}$ & $\mathrm{pH}$ & $\begin{array}{l}\text { Contact time } \\
(\min )\end{array}$ & Ref. \\
\hline Seeds & Petroleum ether & $\begin{array}{l}\text { Cd (II) } \\
\mathrm{Cu}(\text { II) } \\
\mathrm{Co} \text { (II) } \\
\mathrm{Ni} \text { (II) } \\
\mathrm{Pb} \text { (II) }\end{array}$ & 22 & $3.5-8.0$ & 60 & [4] \\
\hline Leaves & $\mathrm{NaOH}$ and Citric acid & $\begin{array}{l}\mathrm{Cd}(\mathrm{II}) \\
\mathrm{Cu}(\mathrm{II}) \\
\mathrm{Ni}(\mathrm{II})\end{array}$ & 40 & 5.0 & 50 & [32] \\
\hline Bark & Original state & $\mathrm{Ni}(I I)$ & 50 & 6.0 & 60 & [35] \\
\hline Wood & Activated carbon & $\begin{array}{l}\mathrm{Cu}(I I) \\
\mathrm{Ni}(I I) \\
\mathrm{Zn}(I I)\end{array}$ & 30 & 6.0 & 240 & [31] \\
\hline Leaves & $\mathrm{NaOH}$ and Citric acid & $\mathrm{Pb}(I I)$ & 40 & 5.0 & 50 & [34] \\
\hline Bark & Original state & $\mathrm{Pb}(I I)$ & 25 & 5.0 & 30 & [19] \\
\hline Pod & $\begin{array}{l}\text { Original state } \\
\mathrm{NaOH}, \\
\mathrm{H}_{2} \mathrm{SO}_{4} \\
\mathrm{CTAB} \\
\mathrm{HCl} \\
\mathrm{Ca}(\mathrm{OH})_{2} \\
\text { Triton X-100 } \\
\mathrm{H}_{3} \mathrm{PO}_{4} \\
\mathrm{Al}(\mathrm{OH})_{3}\end{array}$ & $\mathrm{Zn}(I I)$ & 30 & 7.0 & 50 & [16] \\
\hline
\end{tabular}




\begin{tabular}{|c|c|c|c|c|c|c|}
\hline Moringa Oleifera & Modifying agent(s) & Heavy metal & $\begin{array}{l}\text { Temperature } \\
\left({ }^{\circ} \mathrm{C}\right)\end{array}$ & $\mathrm{pH}$ & $\begin{array}{l}\text { Contact time } \\
\text { (min) }\end{array}$ & Ref. \\
\hline & SDS & & & & & \\
\hline \multirow[t]{3}{*}{ Shelled seeds } & Original state & $\mathrm{Cd}(\mathrm{II})$ & - & 6.5 & 40 & [15] \\
\hline & & $\mathrm{Cr}(\mathrm{III})$ & & 6.5 & & \\
\hline & & $\mathrm{Ni}(I I)$ & & 7.5 & & \\
\hline \multirow[t]{2}{*}{ Shells } & Original state & As (III) & - & 7.5 & 60 & [43] \\
\hline & & As $(V)$ & & 2.5 & & \\
\hline \multirow[t]{5}{*}{ Husk and pods } & Unmodified & $\mathrm{Pb}(\mathrm{II})$ & 30 & 5.8 & 120 & [3] \\
\hline & CTAB & & & & & \\
\hline & $\mathrm{H}_{3} \mathrm{PO}_{4}$ & & & & & \\
\hline & $\mathrm{H}_{2} \mathrm{SO}_{4}$ & & & & & \\
\hline & $\mathrm{HCl}$ & & & & & \\
\hline Shelled seeds & Original state & $\mathrm{Cd}(\mathrm{II})$ & - & 6.5 & 40 & [14] \\
\hline Seeds & Original state & $\mathrm{Ag}(\mathrm{I})$ & 25 & 6.5 & 20 & [36] \\
\hline Seeds & $\mathrm{NaOH}$ & $\mathrm{Ni}(I I)$ & 25 & $4.0-6.0$ & 5 & [44] \\
\hline
\end{tabular}

CTAB: Cetyl trimethylammonium bromide, SDS: Sodium dodecyl sulfate

Table 3. Study parameters for the removal of metal ions using Moringa oleifera.

\section{Adsorption models}

An important physicochemical aspect in terms of the evaluation of sorption processes is the sorption equilibrium. Adsorption isotherms are a basic requirement in understanding how the adsorbate is distributed between the liquid and solid phases when the adsorption process reaches the equilibrium state $[45,46]$. Over the years a wide variety of isotherm models have been introduced. The most commonly used isotherm models include Langmuir [47], Freundlich [48], Dubinin-Radushkevich [49] and Temkin [50].

It can be observed that in most of the cases the Langmuir adsorption model has been successfully used to predict metal adsorption processes. The Langmuir isotherm model assumes monolayer adsorption onto an adsorbent surface containing a finite number of identical sites and without interaction between adsorbed molecules. The Langmuir isotherm model assumes that: each site can accommodate only one molecule or atom; the surface is energetically homogenous; there is no interaction between neighboring adsorbed molecules or atoms; and there are no phase transitions [51]. The Langmuir equation is expressed as follows:

$$
q_{e}=\frac{q_{m} K_{L} C_{e}}{1+K_{\mathrm{L}} C_{e}}
$$


where $q_{e}$ is the amount of metal adsorbed at equilibrium $\left(\mathrm{mg} \mathrm{g}^{-1}\right), C_{e}$ is the concentration of metal in solution at equilibrium $\left(\mathrm{mg} \mathrm{L}^{-1}\right)$, and $q_{m}\left(\mathrm{mg} \mathrm{g}^{-1}\right)$ and $K_{L}\left(\mathrm{~L} \mathrm{mg}^{-1}\right)$ are the Langmuir constants related to the adsorption capacity (amount of adsorbate needed to form a complete monolayer) and adsorption energy, respectively. The constants $q_{m}$ and $K_{L}$ can be calculated from the intercepts and the slopes of the linear plots of $C_{e} / q_{e}$ versus $C_{e}$.

The Freundlich model describes adsorption onto an energetically heterogeneous surface not limited by the monolayer capacity [48]. It can be presented in the following form:

$$
q_{e}=K_{f} C_{e}^{n}
$$

where $q_{e}$ is the amount of metal adsorbed at equilibrium $\left(\mathrm{mg} \mathrm{g}^{-1}\right), C_{e}$ is the concentration of metal in solution at equilibrium $\left(\mathrm{mg} \mathrm{L}^{-1}\right)$, and $K_{f}\left(\mathrm{mg} \mathrm{g}^{-1}\right)(\mathrm{L} \mathrm{mg})^{(1 / \mathrm{n})}$ and $n\left(\mathrm{~g} \mathrm{~L}^{-1}\right)$ are the Freundlich constants related to the multilayer adsorption capacity and adsorption intensity, respectively. According to the theory, $n$ values between 1 and 10 represent favorable adsorption conditions [52]. Values of $K_{f}$ and $n$ can be calculated from the slope and intercept of the plot of $\log q_{e}$ versus $\log C_{e}$. Experimental adsorption results with high coefficient correlation $\left(\mathrm{R}^{2}\right)$ values obtained for Freundlich isotherms have been reported as shown in Table 4.

The Dubinin-Radushkevich model has been used to distinguish between physical and chemical adsorption [53]. The Dubinin-Radushkevich is more general than the Langmuir model because it does not assume a homogenous surface or constant sorption. The DubininRadushkevich equation is given by:

$$
q_{e}=q_{m} e^{\left(-\beta \in^{2}\right)}
$$

where, $q_{m}\left(\mathrm{mg} \mathrm{g}^{-1}\right)$ is the theoretical sorption capacity $\left(\mathrm{mol} \mathrm{g}^{-1}\right), \varepsilon$ is the Polanyi potential which is related to the equilibrium concentration and the constant $\beta$ gives the mean energy of sorption, $E\left(\mathrm{KJ} \mathrm{mol}^{-1}\right)$. The constants $q_{m}$ and $\beta$ are obtained from the intercept and slope of $\ln q_{e}$ versus $\varepsilon^{2}$, respectively. If the magnitude of $E$ is between 8 and $16 \mathrm{KJ} \mathrm{mol}^{-1}$ the adsorption process proceeds by ion-exchange or chemisorptions, while for values of $\mathrm{E}<8 \mathrm{KJ} \mathrm{mol}^{-1}$ the adsorption process is of a physical nature [54]. In [31] reported that the sorption energy $(E)$ values obtained with the Dubinin-Radushkevich model showed that the interaction between metal ions and the adsorbent proceeded principally by physical adsorption.

The Temkin isotherm model is based on the assumption that the heat of adsorption of all the molecules in the layer decreases linearly with coverage due to adsorbent-adsorbate interactions, and the adsorption is characterized by a uniform distribution of binding energies, up to a maximum binding energy [50]. The model is represented by the following equation:

$$
q_{e}=B \ln \left(A C_{e}\right)
$$


where $A\left(\mathrm{Lg}^{-1}\right)$ and $B\left(J \mathrm{mg}^{-1}\right)$ are Temkin isotherm constants relating to adsorption potential and heat of adsorption, respectively. A plot of $q_{e}$ versus $\ln C_{e}$ gives the values of Temkin constants $A$ and $B$. In the adsorption of copper, nickel and zinc onto activated carbon produced from Moringa oleifera wood [31] the Temkin isotherm showed a higher correlation coefficient, which may be due to the linear dependence of the heat of adsorption on low or medium coverage. The repulsive force probably occurs between the different adsorbate species or for intrinsic surface heterogeneity may be associated with the linearity.

Table 4 details some of the results for the biosorption studies using Moringa oleifera which have been reported in the literature from 2006 onwards. From this table it is clear that Moringa oleifera shows versatility, removing a variety metals under favorable conditions and is among the most promising metal biosorbents.

Comparing the Langmuir and Freundlich models, M. oleifera seeds demonstrated a good removal capacity for $\mathrm{Co}(\mathrm{II}), \mathrm{Cu}(\mathrm{II}), \mathrm{Pb}(\mathrm{II}), \mathrm{Cd}(\mathrm{II})$ and $\mathrm{Ag}(\mathrm{I})$, as compared to reports related to other parts of the plant (Table 3). The variations in the removal percentage for metal ions can be explained by the different ionic radii of chemical species. In general, for the single metal solutions, ions with larger ionic radii are preferentially adsorbed. Among the metals tested, $\mathrm{Pb}$ (II) has the largest ionic radius and hence shows the highest adsorption percentage, whereas $\mathrm{Co}(\mathrm{II})$ presents the lowest level of adsorption [55].

Kinetics models are important in evaluating the basic qualities of an adsorbent as well as the time required for the removal of particular metals, the effectiveness of the adsorbent and the identification of the types of mechanisms involved in an adsorption system [56-58]. In order to investigate the mechanism of biosorption and its potential rate-controlling steps, which include the mass transfer and chemical reaction processes, kinetics models are exploited to test experimental data obtained in kinetics studies. These usually show an initial period of rapid metal adsorption with a subsequent decreased until reaching equilibrium of the system. This occurs due to the rapid adsorption of metallic ions by the surface of the adsorbent followed by a step of slow diffusion of ions from the surface film to the adsorption sites in the micropores which are less accessible [59].

In practice, the kinetic studies are carried out in batch experiments, typically varying the adsorbate concentration, the adsorbent mass, the agitation time and the temperature, as well as the type of adsorbent and adsorbate. Subsequently, the data are processed and used in the linear regression to determine the kinetics model which provides the best fit. However, for the validity of the order of the adsorption process two criteria should be evaluated, the first based on the regression coefficient $\left(R^{2}\right)$ and the second on the calculated $q_{e}$ values, which must approach the experimental $q_{e}$ [60]. The main models used to evaluate the kinetics model profile are pseudo-first-order and pseudo-second order. However, other models are also are applied, such as Bangham's model and the Weber and Morris sorption kinetic model. 


\begin{tabular}{|c|c|c|c|c|c|c|c|}
\hline \multirow[t]{2}{*}{ Heavy metal } & \multicolumn{3}{|c|}{ Langmuir model } & \multicolumn{3}{|l|}{ Freundlich model } & \multirow[t]{2}{*}{ Ref. } \\
\hline & $\begin{array}{l}q m \\
\left(\mathrm{mg} \mathrm{g}^{-1}\right)\end{array}$ & $\begin{array}{l}\mathrm{KL} \\
\left(\mathrm{L} \mathrm{mg}^{-1}\right)\end{array}$ & $\mathrm{R}^{2}$ & $\begin{array}{l}\text { Kf } \\
\left(\mathrm{mg} \mathrm{g}^{-1}\right)\left(\mathrm{L} \mathrm{mg}^{)(1 / n)}\right.\end{array}$ & $\begin{array}{l}n \\
\left(g^{-1}\right)\end{array}$ & $\mathbf{R}^{2}$ & \\
\hline $\mathrm{Cd}(\mathrm{II})$ & 171.37 & 0.0370 .0290 .023 & $>0.99$ & - & - & - & [32] \\
\hline $\mathrm{Cu}(\mathrm{II})$ & 167.90 & & $>0.99$ & & & & \\
\hline $\mathrm{Ni}(\mathrm{II})$ & 163.88 & & $>0.99$ & & & & \\
\hline $\mathrm{Ni}(I I)$ & 30.38 & 0.31 & 0.9994 & - & - & - & [35] \\
\hline $\mathrm{Cu}(\mathrm{II})$ & 11.534 & 0.2166 & 0.9979 & 3.8563 & 2.9214 & 0.9976 & [31] \\
\hline $\mathrm{Zn}(\mathrm{II})$ & 17.668 & 0.1430 & 0.9528 & 3.7708 & 2.2528 & 0.9996 & \\
\hline $\mathrm{Ni}(\mathrm{II})$ & 19.084 & 0.6165 & 0.9973 & - & - & - & \\
\hline $\mathrm{Pb}(\mathrm{II})$ & 209.54 & 0.038 & $>0.99$ & - & - & - & [34] \\
\hline $\mathrm{Ni}(\mathrm{II})$ & 29.6 & - & 0.9913 & - & - & - & {$[44]$} \\
\hline $\mathrm{Ag}(\mathrm{II})$ & 23.13 & 0.1586 & 0.9935 & - & - & - & [36] \\
\hline $\mathrm{Zn}(\mathrm{II})$ & 52.08 & 0.150 & 0.9994 & 50.35 & - & 0.9953 & [16] \\
\hline $\mathrm{Cd}(\mathrm{II})$ & 1.06 & 0.51 & 0.94 & - & - & - & [15] \\
\hline $\mathrm{Cr}(I I I)$ & 1.01 & 0.40 & 0.96 & & & & \\
\hline $\mathrm{Ni}(\mathrm{II})$ & 0.94 & 0.34 & 0.96 & & & & \\
\hline As (III) & 1.59 & 0.04 & 0.96 & - & - & - & [43] \\
\hline As $(V)$ & 2.16 & 0.09 & 0.98 & & & & \\
\hline $\mathrm{Pb}(\mathrm{II})$ & - & - & 0.9981 & - & - & - & [3] \\
\hline $\mathrm{Pb}(\mathrm{II})$ & - & - & - & 8.6 & 2.8 & 0.9981 & [19] \\
\hline $\mathrm{Cd}(\mathrm{II})$ & - & - & - & 3.04 & 1.37 & - & [14] \\
\hline
\end{tabular}

Table 4. Langmuir and Freundlich isotherm parameters for Moringa oleifera.

The pseudo-first order equation, also known as the Lagergren equation, is expressed as follows $[16,61]$ :

$$
\log \left(q_{e}-q_{t}\right)=\log q_{e}-\frac{k_{1}}{2.303} t
$$

where $q_{t}$ and $q_{e}\left(\mathrm{mg} \mathrm{g}^{-1}\right)$ are the amount of metal ions adsorbed per unit weight of the adsorbent at time $t$ and equilibrium, respectively; and $k_{1}\left(\mathrm{~min}^{-1}\right)$ is the pseudo-first order rate constant of the sorption process and $t(\mathrm{~min})$ is the mixing time [60]. Table 5 presents the data of calculated $q_{e}$ pseudo-first order rate $\left(k_{1}\right)$ and correlation coefficient $\left(R^{2}\right)$. This kinetics model is based on the assumption that the adsorption rate is proportional to the number of free sites available, occurring exclusively onto one site per ion [34, 62].

In most studies discrepancies occurred between the value of $q_{e}$ calculated by the pseudo-first order model and the experimental $q_{e}$ as shown in Table 5, highlighting the inability of this 
model to describe the kinetics of the metal ion adsorption processes. In general, calculated $q_{e}$ values are smaller than the experimental $q_{e}$, which may occur because of a time lag, probably due to the presence of the boundary layer or external resistance at the beginning of the sorption process [63]. Considering the papers detailed in Table 5, only in [43] and [14] used only the pseudo-first order kinetics model to examine the data obtained, even though in the latter case the correlation values obtained were relatively low. In [43] noted no change in the adsorption rate constant when varying the concentrations of $\mathrm{As}(\mathrm{III})$ and $\mathrm{As}(\mathrm{V})$ and therefore this model could describe the adsorption process. In [14] used this model to compare the adsorption rate constants of ternary metal ions and single metal ions and noted that these constants were lower for ternary metal ions. Their explanation for this was that metal ions compete for vacant sites and uptake by binding sites within the shortest possible time.

The pseudo-second-order kinetics model is also based on the assumption that the sorption rate is controlled by a chemical sorption mechanism involving electron sharing or electron transfer between the adsorbent and adsorbate [64]. It can be expressed as:

$$
\frac{t}{q_{t}}=\frac{1}{k_{2} q_{e}^{2}}+\frac{t}{q_{e}}
$$

where $q_{t}$ and $q_{e}\left(\mathrm{mg} \mathrm{g}^{-1}\right)$ are the amount of metal ions adsorbed per unit weight of the adsorbent at time $t$ and equilibrium, respectively; and $k_{2}\left(\mathrm{~g} \mathrm{mg}^{-1} \mathrm{~min}^{-1}\right)$ is the pseudo-second order rate constant of the sorption process and $t$ ( $\mathrm{min}$ ) is the mixing time.

Table 5 presents the data of calculated $q_{e}$, pseudo-second order rate $\left(k_{2}\right)$ and correlation coefficient $\left(R^{2}\right)$. For most of the pseudo-second order kinetics models the calculated $q_{e}$ values approach the experimental $q_{e}$ values and the correlation coefficients are close to 1 , indicating a good ability of this model to describe the kinetics of the metal ion adsorption process. This observation indicates that the rate-limiting steps in the biosorption of metallic ions are chemisorption involving valence forces through the sharing or exchange of electrons between the sorbent and the sorbate, complexation, coordination and/or chelation, in which mass transfer in the solution was not involved.

Considering that neither the pseudo-first-order nor the pseudo-second-order model can identify the diffusion mechanism, other kinetic models are needed to study this process, such as Bangham's model and the Weber and Morris sorption kinetics model [65]. The latter model is also known as the intra-particle diffusion model, this process in many cases being the ratelimiting step, which can be determined through the following equation:

$$
q_{t}=k_{i d} t^{1 / 2}+c_{i d}
$$

where $q_{t}\left(\mathrm{mg} \mathrm{g}^{-1}\right)$ is the amount of metal ions adsorbed per unit weight of the adsorbent at time $t, c_{i d}\left(\mathrm{mg} \mathrm{g}^{-1}\right)$ is a constant of Weber and Morris, and $k_{i d}\left(\mathrm{mg} \mathrm{g}^{-1} \mathrm{~min}^{-1 / 2}\right)$ is the intra-particle diffusion rate constant and $t(\mathrm{~min})$ is the mixing time [66]. The value of the intercept gives an idea of the thickness of the boundary layer, i.e., the larger the intercept the greater the boundary 
layer effect will be. When there is a complete fit of the model the value of $c_{i d}$ should be zero, and the deviation of this constant is due to differences in the mass transfer rate during the initial and final stages of adsorption. This is indicative that there is some degree of boundary layer control and shows that the intra-particle diffusion is not the only rate-limiting step, and thus several processes operating simultaneously may control the adsorption [34].

According to this model, if the plot of $q_{t}$ versus $t^{1 / 2}$ gives a straight line, then the sorption process is controlled by intra-particle diffusion, while if the data exhibit multi-linear plots then two or more steps influence the adsorption process [67]. In two studies performed in [32, 19], multilinear plots were observed with three distinct steps involved in the biosorption, the initial region of the curve relative relating to the adsorption on the external surface. The second region corresponds to the gradual uptake, where the intra-particle diffusion is the rate-limiting step. The final plateau region indicates the equilibrium uptake.

In reference [3] compared different types of carbon through the $k_{i d}$ values and observed that the effect of intra-particle diffusion may be significantly increased by chemically modifying the adsorbents. Although none of the data collected in the studies detailed in Table 5 were well-described by the kinetics model proposed by Weber and Moris, the intraparticle diffusion may not be the only rate-limiting step in these studies.

Bangham's model evaluates whether pore diffusion is the only rate-controlling step in the adsorption process [65] and can be represented by the following equation:

$$
\log \left[\log \left(\frac{c_{o}}{c_{o}-q_{t} m}\right)\right]=\log \left(\frac{k_{o} m}{2.303 V}\right)+\sigma \log t
$$

where $q_{t}\left(\mathrm{mg} \mathrm{g}^{-1}\right)$ is the amount of metal ions adsorbed per unit weight of the adsorbent at time $t ; c_{o}\left(\mathrm{mg} \mathrm{L}^{-1}\right)$ is the initial metal ion concentration in liquid phase; $m\left(\mathrm{~g} \mathrm{~L}^{-1}\right)$ is adsorbent concentration at time $t(\mathrm{~min}) ; V(\mathrm{~L})$ solution volume, $t(\mathrm{~min})$ is the mixing time and $k_{o}\left(\mathrm{~L} \mathrm{~g} \mathrm{~g}^{-1}\right)$ and $\sigma(\sigma<1)$ are constants of Bangham's model. Of the studies published, only in [3] used Bangham's kinetic model to compare the rate constants for the adsorption of $\mathrm{Pb}$ (II) onto different types of functionalized carbon prepared from the seed husks and pods of $M$. oleifera and thereby assess the efficiency of the functionalization of this material.

The temperature is reportedly an important parameter for the adsorption of metal ions. An increase or decrease in temperature can cause a change in the amount of metal removed or adsorbed by the adsorbent. A change in temperature causes a change in the thermodynamic parameters of free energy $\left(\Delta G^{\circ}\right)$, enthalpy $\left(\Delta H^{\circ}\right)$ and entropy $\left(\Delta S^{\circ}\right)$. These parameters are important to understand the adsorption mechanism [68]. For a given temperature, a phenomenon is considered to be spontaneous if the $\Delta G^{\circ}$ has a negative value. Moreover, if $\Delta H^{\circ}$ is positive the process is endothermic and if it is negative the process is exothermic [69]. Negative values of $\Delta S^{\circ}$ show a decreased randomness or increased order at the metal-biomass interface. The positive value showed a change in the biomass structure during the sorption process, causing an increase in the disorder of the system [68]. The parameters $\Delta G^{\circ}\left(\mathrm{kJ} \mathrm{mol}^{-1}\right), \Delta H^{\circ}(\mathrm{kJ}$ $\left.\mathrm{mol}^{-1}\right)$ and $\Delta S^{\circ}\left(\mathrm{J} \mathrm{mol}^{-1} \mathrm{~K}^{-1}\right)$ can be evaluated from the following equations [70]. 


$$
\begin{gathered}
\Delta G^{\circ}=-R T \ln K_{c} \\
\ln K_{c}=-\frac{\Delta H^{\circ}}{R T}+\frac{\Delta S^{\circ}}{R}
\end{gathered}
$$

where $R\left(8.314 \mathrm{~J} \mathrm{~mol}^{-1} \mathrm{~K}^{-1}\right)$ is the gas constant, $T(\mathrm{~K})$ the absolute temperature and $K_{c}\left(\mathrm{~mL} \mathrm{~g}^{-1}\right)$ the standard thermodynamic equilibrium constant defined by $q_{e} / C_{e} . \Delta H^{\circ}$ and $\Delta S^{\circ}$ can be determined from the slope and the intercept of the linear plot of $\operatorname{Ln} K_{c}$ versus 1/T.

The studies performed on Moringa oleifera using chemically-modified leaves for the adsorption of $\mathrm{Pb}$ (II) [34], bark for $\mathrm{Ni}(\mathrm{II})$ [35] and leaves for $\mathrm{Cd}(\mathrm{II}), \mathrm{Cu}(\mathrm{II})$ and $\mathrm{Ni}(\mathrm{II})$ [32] showed the endothermic nature and spontaneity of the adsorption process. The positive values of $\Delta S^{\circ}$ suggest an increase in randomness at the solid/liquid interface with some structural changes in the sorbate.

\section{Final considerations}

Although the biosorption of heavy metals from aqueous solutions is a relatively new process that has proven very promising in the removal of contaminants from aqueous effluents, offering significant advantages like the low-cost, availability, profitability, easy of operation and efficiency. Other technologies have also been very attractive ensuring an appropriate process to treat industrial waste effluents [71-77]. However, biosorption is becoming a potential alternative to the existing technologies for the removal and/or recovery of toxic metals from wastewater. The major advantages of biosorption technology are its effectiveness in reducing the concentration of heavy metal ions to very low levels and the use of inexpensive biosorbent materials.

\section{Conclusions}

The studies described herein indicate that Moringa oleifera seeds are an alternative sorbent for metal ion removal from contaminated waters. This can be found in most papers which report 60 to $90 \%$ removal of metals (Cd(II), Cu(II), Ni(II), Pb(II), As(III), As(V), Cr(III) and Zn(II)). In these cases, not only the seeds were used, but also leaves, bark and pods showing the great versatility of this plant. The results show that even with the high heterogeneity of the matrix confirmed through characterization techniques there is a great potential for the application of these seeds in effluent treatment without component separation, which makes the process economically and technically attractive.

Biosorption is the most economical and eco-friendly method for the removal of heavy metals from domestic as well as industrial wastewater and it is particularly important to promote the development of biosorption for industrial processes. Notable advantages are: (a) low cost of 


\begin{tabular}{|c|c|c|c|c|c|c|c|c|c|c|}
\hline \multirow[b]{2}{*}{ Metal } & \multirow{2}{*}{$\begin{array}{c}\mathrm{c}_{\mathrm{o}} \\
\left(\mathrm{mg} \mathrm{L}^{-1}\right)\end{array}$} & \multirow{2}{*}{$\begin{array}{c}\text { qe, exp } \\
\left(m g g^{-1}\right)\end{array}$} & \multicolumn{3}{|c|}{ Pseudo-first-order } & \multicolumn{4}{|c|}{ Pseudo-second-order } & \multirow[t]{2}{*}{ Ref. } \\
\hline & & & $\begin{array}{c}\text { qe } \\
\left(\mathrm{mg} \mathrm{g}^{-1}\right)\end{array}$ & $\begin{array}{c}\mathrm{k} 1(\min \\
-1)\end{array}$ & $\mathbf{R}^{2}$ & qe $\left(\mathrm{mg} \mathrm{g}^{-1}\right)$ & $\begin{array}{c}\mathrm{k} 2\left(\mathrm{~g} \mathrm{mg}^{-1}\right. \\
\left.\mathrm{min}^{-1}\right)\end{array}$ & $\begin{array}{c}\mathrm{h}_{0}\left(\mathrm{mg} \mathrm{g}^{-1}\right. \\
\left.\mathrm{min}^{-1}\right)\end{array}$ & $\mathbf{R}^{2}$ & \\
\hline \multirow{3}{*}{ Zn (II) } & $50^{\mathrm{a}}$ & 45.00 & - & - & - & 46.94 & $4.5110-4$ & - & 0.997 & \multirow{3}{*}{16} \\
\hline & $50^{\mathrm{b}}$ & 45.76 & - & - & - & 47.16 & $2.8510-4$ & - & 0.999 & \\
\hline & $50^{c}$ & 42.80 & - & - & - & 43.47 & $2.0410-5$ & - & 0.997 & \\
\hline \multirow{5}{*}{$\mathrm{Pb}(\mathrm{II})$} & $30^{\mathrm{d}}$ & - & - & - & - & 24.57 & 0.0085 & 5.131 & 0.999 & \multirow{5}{*}{ [3] } \\
\hline & $30^{e}$ & - & - & - & - & 27.70 & 0.0052 & 3.989 & 0.998 & \\
\hline & $30^{f}$ & - & - & - & - & 28.49 & 0.0060 & 4.868 & 0.998 & \\
\hline & $30^{9}$ & - & - & - & - & 29.08 & 0.0062 & 5.243 & 0.999 & \\
\hline & $30^{h}$ & - & - & - & - & 29.46 & 0.0087 & 7.550 & 0.999 & \\
\hline \multirow{4}{*}{$\begin{array}{l}\text { As (III) } \\
\text { As (V) }\end{array}$} & 25 & - & - & 0.047 & - & - & - & - & - & \multirow{4}{*}{43} \\
\hline & 50 & - & - & 0.049 & - & - & - & - & - & \\
\hline & 25 & - & - & 0.063 & - & - & - & - & - & \\
\hline & 50 & - & - & 0.065 & - & - & - & - & - & \\
\hline \multirow{3}{*}{$\begin{array}{l}\mathrm{Cd}(\mathrm{II}) \\
\mathrm{Cr}(\mathrm{III}) \mathrm{Ni}(\mathrm{II})\end{array}$} & 25 & 1.06 & - & 0.51 & - & - & - & - & - & \multirow{3}{*}{14} \\
\hline & 25 & 1.01 & - & 0.40 & - & - & - & - & - & \\
\hline & 25 & 0.94 & - & 0.34 & - & - & - & - & - & \\
\hline \multirow{3}{*}{$\mathrm{Pb}(\mathrm{II})$} & 10 & 12.7343 & - & - & - & 13.26 & 15.35 & 0.20 & 0.9974 & \multirow{3}{*}{ [34] } \\
\hline & 25 & 19.8988 & - & - & - & 20.64 & 10.08 & 0.21 & 0.997 & \\
\hline & 40 & 23.9233 & - & - & - & 25.01 & 9.3 & 0.23 & 0.9995 & \\
\hline \multirow{3}{*}{$\mathrm{Pb}(\mathrm{II})$} & 10.4 & 8.7 & - & - & - & 8.8 & 27.8 & 2.5 & 0.9999 & \multirow{3}{*}{ [19 } \\
\hline & 30.1 & 10.2 & - & - & - & 10.3 & 18.2 & 1.9 & 0.9999 & \\
\hline & 50.4 & 12.5 & - & - & - & 12.53 & 12.6 & 1.6 & 0.9998 & \\
\hline \multirow{3}{*}{$\mathrm{Ni}(\mathrm{II})$} & 10 & 9.7 & - & - & - & 10.29 & 1.91 & 2.03 & 0.9971 & \multirow{3}{*}{35} \\
\hline & 25 & 6.74 & - & - & - & 7.14 & 2.70 & 1.38 & 0.9964 & \\
\hline & 50 & 3.27 & - & - & - & 3.43 & 12.74 & 1.05 & 0.996 & \\
\hline $\mathrm{Cu}(\mathrm{II})$ & 30 & 8.3406 & - & - & - & 8.3264 & 0.0848 & - & 0.9998 & \multirow{3}{*}{ [31] } \\
\hline Zn(II) & 30 & 13.2537 & - & - & - & 13.2450 & 0.2457 & - & 1 & \\
\hline \multirow[t]{4}{*}{$\mathrm{Ni}(\mathrm{II})$} & 30 & 9.5847 & - & - & - & 9.6154 & 0.0957 & - & 0.9999 & \\
\hline & 10 & 13.54 & - & - & - & 10.99 & 1.39 & 2.73 & 0.9951 & \multirow{9}{*}{ [32] } \\
\hline & 25 & 13.80 & - & - & - & 10.50 & 1.46 & 3.09 & 0.9969 & \\
\hline & 40 & 20.86 & - & - & - & 15.24 & 1.22 & 5.61 & 0.9981 & \\
\hline Cd (II) & 10 & 11.92 & - & - & - & 11.03 & 3.4 & 5.58 & 0.9992 & \\
\hline $\mathrm{Cu}(\mathrm{II})$ & 25 & 13.55 & - & - & - & 12.45 & 1.66 & 3.37 & 0.9958 & \\
\hline \multirow[t]{4}{*}{$\mathrm{Ni}(I I)$} & 40 & 16.01 & - & - & - & 12.86 & 1.56 & 4.31 & 0.9977 & \\
\hline & 10 & 10.24 & - & - & - & 10.24 & 1.51 & 1.70 & 0.9951 & \\
\hline & 25 & 12.49 & - & - & - & 12.49 & 1.31 & 2.29 & 0.9952 & \\
\hline & 40 & 14.07 & - & - & - & 14.07 & 1.52 & 3.27 & 0.9967 & \\
\hline
\end{tabular}

Table 5. Kinetics parameters for metal biosorption using Moringa oleifera. 
the biosorbent, (b) high efficiency for metal removal at low concentration, (c) potential for biosorbent regeneration and metal valorization, (d) high sorption and desorption rates, (e) limited generation of secondary residues, and (f) relatively environmentally-friendly life cycle of the material (easy to eliminate compared to conventional resins, for example).

However, after the metal removal from aqueous solutions by the biomass, the recovery of the metal is an important issue. This can be achieved through a metal desorption process, aimed at weakening the metal-biomass linkage. Thus, studies to evaluate the reversibility of the adsorption reactions involved in the biosorption of heavy metals are of great importance. The problems associated with the disposal of exhausted adsorbent can be solved either by its activation or incineration or its disposal after proper treatment. For biosorption and desorption processes, another important aspect is the biosorbent reuse in successive biosorption-desorption cycles, the viability of which is determined by the cost-benefit relationship between the loss in biosorption capacity during the desorption steps and the operational yield in the metal recovery. Thus, further studies need to focus on the development of new clean environmentally-acceptable technologies.

\section{Acknowledgements}

The authors are grateful for financial support from the government agencies Conselho Nacional de Desenvolvimento Científico e Tecnológico (CNPq), Fundação de Amparo à Pesquisa do Estado de Minas Gerais (FAPEMIG), Fundação de Amparo à Pesquisa do Estado de Goiás (FAPEG) and Coordenação de Aperfeiçoamento de Pessoal de Nível Superior (CAPES).

\section{Nomenclature}

\begin{tabular}{ll}
\hline$A$ & Temkin isotherm constant relating to adsorption potential, $\left(\mathrm{L} \mathrm{g}^{-1}\right)$ \\
\hline$B$ & Temkin isotherm constant relating to heat of adsorption, $\left(\mathrm{J} \mathrm{mg}^{-1}\right)$ \\
\hline$C_{0}$ & mean energy of sorption, $\mathrm{E}\left(\mathrm{KJ} \mathrm{mol}^{-1}\right)$ \\
\hline$C_{\mathrm{e}}$ & initial metal ion concentration in liquid phase, $\left(\mathrm{mg} \mathrm{L}^{-1}\right)$ \\
\hline$C_{\text {id }}$ & concentration of metal in solution at equilibrium, $\left(\mathrm{mg} \mathrm{L}^{-1}\right)$ \\
\hline CAPES & Constant of the Weber and Morris model, $\left(\mathrm{mg} \mathrm{g}^{-1}\right)$ \\
\hline CNPq & National Council for Scientific and Technological Development \\
\hline$\varepsilon$ & Polanyi potential which is related to the equilibrium concentration \\
\hline FAPEMIG & Research Foundation of the State of Minas Gerais \\
\hline FAPEG & Research Foundation of the State of Goiás \\
\hline
\end{tabular}




\begin{tabular}{|c|c|}
\hline FT-IR & Fourier transform infrared \\
\hline$\Delta G^{\circ}$ & free energy, $\left(\mathrm{kJ} \mathrm{mol}^{-1}\right)$ \\
\hline$\Delta H^{\circ}$ & enthalpy, $\left(\mathrm{kJ} \mathrm{mol}^{-1}\right)$ \\
\hline$K_{c}$ & standard thermodynamic equilibrium constant defined by $q_{e} / C_{e}\left(\mathrm{~mL} \mathrm{~g}^{-1}\right)$ \\
\hline $\mathrm{K}_{\mathrm{L}}$ & Langmuir constant related to adsorption energy, $\left(\mathrm{L} \mathrm{mg}^{-1}\right)$ \\
\hline $\mathrm{K}_{\mathrm{f}}$ & Freundlich constant related to the multilayer adsorption capacity \\
\hline$k_{1}$ & pseudo-first order rate constant of the sorption process, $\left(\mathrm{min}^{-1}\right)$ \\
\hline$k_{2}$ & pseudo-second order rate constant of the sorption process, $\left(\mathrm{g} \mathrm{mg}^{-1} \mathrm{~min}^{-1}\right)$ \\
\hline$k_{\text {id }}$ & intra-particle diffusion rate constant, $\left(\mathrm{mg} \mathrm{g}^{-1} \mathrm{~min}^{-1 / 2}\right)$ \\
\hline$k_{0}$ & constant of the Bangham's model, $\left(\mathrm{L} \mathrm{g}^{-1}\right)$ \\
\hline$\sigma$ & constant of the Bangham's model \\
\hline$m$ & adsorbent concentration at time $t(\min ),\left(\mathrm{g} \mathrm{L}^{-1}\right)$ \\
\hline $\mathrm{n}$ & Freundlich constant related to the multilayer adsorption intensity \\
\hline $\mathrm{q}_{\mathrm{e}}$ & amount of metal adsorbed per unit weight of the adsorbent at equilibrium, ( $\left.\mathrm{mg} \mathrm{g}^{-1}\right)$ \\
\hline $\mathrm{q}_{\mathrm{m}}$ & Langmuir constant related to the adsorption capacity, $\left(\mathrm{mg} \mathrm{g}^{-1}\right)$ \\
\hline$\underline{q_{t}}$ & amount of metal ions adsorbed per unit weight of the adsorbent at time $t$, ( $\mathrm{mg} \mathrm{g}^{-1}$ ) \\
\hline$R$ & gas constant, $\left(8.314 \mathrm{~J} \mathrm{~mol}^{-1} \mathrm{~K}^{-1}\right)$ \\
\hline $\mathrm{R}^{2}$ & coefficient correlation \\
\hline$\Delta S^{\circ}$ & entropy, $\left(\mathrm{J} \mathrm{mol}^{-1} \mathrm{~K}^{-1}\right)$ \\
\hline SEM & scanning electron microscopy \\
\hline$t$ & mixing time, (min) \\
\hline$T$ & absolute temperature, $(\mathrm{K})$ \\
\hline TG & thermogravimetric \\
\hline US EPA & United States Environmental Protection Agency \\
\hline V & solution volume, (L) \\
\hline $\mathrm{XRD}$ & X-ray diffraction \\
\hline
\end{tabular}

\section{Author details}

Cleide S. T. Araújo', Dayene C. Carvalho², Helen C. Rezende², Ione L. S. Almeida², Luciana M. Coelho ${ }^{3}$, Nívia M. M. Coelho ${ }^{2 *}$, Thiago L. Marques² and Vanessa N. Alves ${ }^{2}$

*Address all correspondence to: nmmcoelho@ufu.br

1 State University of Goiás, Anápolis, GO, Brazil

2 Institute of Chemistry, Federal University of Uberlândia, Uberlândia, MG, Brazil

3 Department of Chemistry, Federal University of Goiás, Catalão, GO, Brazil 


\section{References}

[1] Miliarum: Ingenieria Civil y Medio Ambiente. Cursos Edafología on line: Contaminación por metales pesados. http://www.miliarium.com/Marcos/SuelosContaminados.asp (accessed 27 September 2012).

[2] Duffus JH. "Heavy metals" - A meaningless term? (IUPAC Techinical Report). Pure and Applied Chemistry 2002; 74(5) 793-807.

[3] Nadeem M, Mahmooda A, Shahid SA, Shah SS, Khalid AM, McKaye G. Sorption of lead from aqueous solution by chemically modified carbon adsorbents. Journal of Hazardous Materials 2006; 138(3) 604-13.

[4] Obuseng V, Nareetsile F, Kwaambwa HM. A study of the removal of heavy metals from aqueous solutions by Moringa oleifera seeds and amine-based ligand 1,4bis[N,N-bis(2-picoyl)amino]butane. Analytica Chimica Acta 2012; 730 87-92.

[5] Zevenhoven R, Kilpinen P. Control of pollutants in flue gases and fuel gases. Finland: Espoo; 2001.

[6] EPA: Environmental Protection Agency. National Primary Drinking Water Regulations. http://www.biovir.com/Images/pdf054.pdf (accessed 27 September 2012).

[7] Babel S, Kurniawan TA. Cr(VI) removal from synthetic wastewater using coconut shell charcoal and commercial activated carbon modified with oxidizing agents and/or chitosan. Chemosphere 2004; 54(7) 951-67.

[8] Bai RS, Abraham TE. Low-cost supports used to immobilize fungi and reliable technique for removal hexavalent chromium in wastewater. Bioresource Technology 2003; 87(17) 17-26.

[9] Petroni SLG, Pires MAF, Munita CS. Adsorção de zinco e cádmio em colunas de turfa. Química Nova 2000; 23(4) 477-81.

[10] Volesky B. Detoxification of metal-bearing effluents: biosorption for the next century. Hydrometallurgy 2001; 59(2) 203-16.

[11] Naja G, Murphy V, Volesky B. Biosorption, Metals - Encyclopedia of Industrial Biotechnology. United Kingdom: Wiley; 2010.

[12] Melcakova I, Horvathova H. Study of biomass of reynoutria japonica as a novel biosorbent for removal of metals from aqueous solutions. Czech Republic: GeoScience Engineering; 2010. http://gse.vsb.cz/2010/LVI-2010-1-55-70.pdf (accessed 27 September 2012).

[13] Dermirbas, A, Heavy metal adsorption onto agro-based waste materials: A review. Journal of Hazardous Materials 2008; 157 220-29 
[14] Sharma P, Kumari P, Srivastava MM, Srivastava S. Removal of cadmium from aqueous system by shelled Moringa oleifera Lam seed powder. Bioresource Technology 2006; 97 299-305.

[15] Sharma P, Kumari P, Srivastava MM, Srivastava S. Ternary biosorption studies of $\mathrm{Cd}(\mathrm{II}), \mathrm{Cr}(\mathrm{III})$ and $\mathrm{Ni}(\mathrm{II})$ on shelled Moringa oleifera seeds. Bioresource Technology 2007; 98 474-77.

[16] Bhatti HN, Mumtaz B, Hanif MA, Nadeem R. Removal of Zn(II) ions from aqueous solution using Moringa oleifera Lam. (horseradish tree) biomass. Process Biochemistry $2007 ; 42$ 547-53.

[17] Keer WE, Silva AR. "Moringa: uma nova hortaliça para o Brasil”. Uberlândia: UFU/ DIRIU, 1999.

[18] Almeida ILS. Avaliação da capacidade de adsorção da torta da Moringa oleifera para BTEX em amostras aquosas. Masters dissertation. Federal University of Uberlândia; 2010.

[19] Reddy DHK, Seshaiah K, Reddy AVR, Rao MM, Wang MC. Biosorption of Pb2+ from aqueous solutions by Moringa oleifera bark: equilibrium and kinetic studies. Journal of Hazardous Materials 2010; 174 831-838.

[20] Nautiyal BP, Venkataraman KG. Moringa (drumstick) - an ideal tree for social forestry: growing conditions and uses - part 1. Myforest 1987; 23(1) 53-8.

[21] Ndabigengesere A, Narasiah KS, Talbot BG. Active agents and mechanism of coagulation of turbid waters using Moringa oleifera. Water Research 1995; 29(2) 703-10.

[22] Jahn SAA. Proper use Moringa oleifera for food and water purification - Selection of clones and growing of annual short-stem. Pflanzenzucht 1989; 4 22-5.

[23] Oliveira JTA, Silveira SB, Vasconcelos IKM, Cavada BS, Moreira RA. Compositional and nutritional attributes of seeds from the multiple purpose tree Moringa oleifera Lamarck. Journal of the Science of Food and Agriculture 1999; 79 815-20.

[24] Olsen A. Low technology water purification by bentonite clay and Moringa oleifera seed flocculation as performed in Sudanese village: effects on Schistoma mansoni cercariae. Water Research 1987; 21(5) 517-22.

[25] Madsen M, Schumundt J, Omer EFE. Effect of watter coagulation by seeds of Moringa oleifera on bacterial concentration. Journalof tropical Medicine and Hygiene 1987; 90(3)101-9.

[26] Bennett RN, Mellon FA, Foidl N, Pratt JH, Dupont MS, Perkins L, Kroon A. Profiling Glucosinolates and Phenolics in Vegetative and Reproductive Tissues of the MultiPurpose Trees Moringa oleifera L. (Horseradish Tree) and Moringa stenopetala L. Journal of Agricultural and Food Chemistry 2003; 51(12) 3546-53. 
[27] Moreira DR. Desenvolvimento de adsorventes naturais para tratamento de efluentes de galvanoplastia. Masters dissertation. Pontifical Catholic University of Rio Grande do Sul; Porto Alegre; 2010.

[28] Davis TA, Mucci A, Volesky B. A review of the biochemistry of heavy metal biosorption by brown algae. Water Research 2003; 37(18) 4311-30.

[29] Schneider IAH, Rubio J. Plantas Aquáticas: Adsorventes Naturais para a Melhoria da Qualidade das Águas, 2003. XIX Prêmio Jovem Cientista - 2003 - Água: Fonte de Vida, Porto Alegre, Brazil, School of Engineering, Federal University of Rio Grande do Sul, 2003.

[30] Pagnanelli F, Mainelli S, Veglio F, Toro L. Heavy metal removal by olive pomace: biosorbent characterization and equilibrium modeling. Chemical Engineering Science 2003; 58 4709-17.

[31] Kalavathy MH, Miranda LR. Moringa oleifera-A solid phase extractant for the removal of copper, nickel and zinc from aqueous solutions. Chemical Engineering Journal 2012; 158 188-99.

[32] Reddy DHK, Seshaiaha K, Reddyb AVR, Leec SM. Optimization of Cd(II), Cu(II) and $\mathrm{Ni}(\mathrm{II})$ biosorption by chemically modified Moringa oleifera leaves powder. Carbohydrate Polymers 2012; 88 1077-86.

[33] Brito ES, Damasceno LF, Gallão MI. Avaliação química e estrutural da semente de moringa. Revista Ciência Agronômica 2006; 37 106-9.

[34] Reddy DHK, Harinatha Y, Seshaiaha K, Reddy AVR. Biosorption of $\mathrm{Pb}$ (II) from aqueous solutions using chemically modified Moringa oleifera tree leaves. Chemical Engineering Journal 2010; 162 626-34.

[35] Reddy DHK, Ramana DKV, Seshaiah K, Reddy AVR. Biosorption of Ni(II) from aqueous phase by Moringa oleifera bark, a low cost biosorbent. Desalination 2011; 268 150-57.

[36] Araújo CST, Melo EI, Alves VN, Coelho NMM. Moringa oleifera Lam. seeds as a natural solid adsorbent for removal of AgI in aqueous solutions. Journal of the Brazilian Chemical Society 2010; 21 1727-32.

[37] Fifield FW, Kealey D. Principles and Practice of Analytical Chemistry. Oxford: Blackwell Science; 2000.

[38] Anwar F, Rashid U. Physico-chemical characteristics of Moringa oleifera seeds and seeds oil from a wild provenance of Pakistan. Pakistan Journal of Botany 2007; 39(5) 1443-53.

[39] Pereira GM, Arruda MAZ. Trends in preconcentration procedures for metal determination using atomic spectrometry techniques. Microchimica Acta 2003; 141 115-31. 
[40] Senthilkumaar S, Bharathi S, Nithyanandhi D, Subburam V. Biosorption of toxic heavy metals from aqueous solutions. Bioresource Technology 2000; 75 163-5.

[41] Alves VN, Mosquetta R, Coelho NMM, Bianchin JN, Roux KCP, Martendal E, Carasek E. Determination of cadmium in alcohol fuel using Moringa oleifera seeds as a biosorbent in an on-line system coupled to FAAS. Talanta 2010; 80(3) 1133-38.

[42] Marshall WE, Johns MM. Agricultural by-products as metal adsorbents: sorption properties and resistance to mechanical abrasion. Journal of Chemical Technology 1996; 66(2) 192-8.

[43] Kumari P, Sharma P, Srivastava S, Srivastava MM. Biosorption studies on shelled Moringa oleifera Lamarck seed powder: removal and recovery of arsenic from aqueous system. International Journal Mineral Process 2006; 78 131-9.

[44] Marques TL, Alves VN, Coelho LM, Coelho NMM. Removal of Ni(II) from aqueous solution using Moringa oleifera seeds as a bioadsorbent. Water Science \& Technology 2012; 68 1435-40.

[45] Shen D, Fan J, Zhou W, Gao B, Yue Q, Kang Q. Adsorption kinetics and isotherm of anionic dyes onto organo-bentonite from single and multisolute systems. Journal of Hazardous Materials 2009; 172 99-107.

[46] Abdullah MA, Chiang L, Nadeem M. Comparative evaluation of adsorption kinetics and isotherms of a natural product removal by Amberlite polymeric adsorbents. Chemical Engineering Journal 2009; 146 370-6.

[47] Ma X, Li L, Yang L, Su C, Wang K, Yuan S, Zhou J. Adsorption of heavy metals ions using hierarchical CaCO3-maltose meso/macroporous hybrid materials: Adsorption isotherms and kinetic studies. Journal of Hazardous Materials 2012; 209-210 467-477.

[48] Tofighy MA, Mohammadi T. Adsorption of divalent heavy metal ions from water using carbon nanotube sheets. Journal of Hazardous Materials 2011; 185 140-7.

[49] Olu-owolabi BI, Oputu OU, Adebowale KO, Ogunsolu O, Olujimi OO. Biosorption of $\mathrm{Cd} 2+$ and $\mathrm{Pb} 2+$ ions onto mango stone and cocoa pod waste: Kinetic and equilibrium studies. Scientific Research and Essays 2012; 7(15) 1614-29.

[50] Kumar PS, Ramalingam S, Senthamarai C, Niranjanaa M, Vijayalakshmi P, Sivanesan S. Adsorption of dye from aqueous solution by cashew nut Shell: Studies on equilibrium isotherm, kinetics and thermodynamics of interactions. Desalination 2010; 261 $52-60$.

[51] Mahmoud DK, Salleh MAM, Karim WAA. Langmuir model application on solid-liquid adsorption using agricultural wastes: Environmental application review. Journal of Purity, Utility Reaction and Environment 2012; 1(4) 170-99. 
[52] Nwabanne JT, Igbokwe PK. Mechanism of cooper (II) removal from aqueous solution using activated carbon prepared from different agricultural materials. International Journal of Multidisciplinary Sciences and Engineering 2012; 3(7) 46-52.

[53] Kumar PS, Ramalingam S, Kirupha SD, Murugesan A, Vidhyadevi T, Sivanesan S. Adsorption behavior of nickel (II) onto cashew nut Shell: equilibrium. Thermodynamics, kinetics, mechanism and process design. Chemical Engineering Journal 2011; 167 122-31.

[54] Kumar PS, Ramalingan S, Sathyaselvabala V, Kirupha SD, Murugesan A, Sivanesan $\mathrm{S}$. Removal of cadmium(II) from aqueous solution by agricultural waste cashew nut shell. Korean Journal of Chemical Engineering 2012; 29(6) 756-68.

[55] Matos GD, Arruda MAZ. Online preconcentration/determination of cadmium using grape bagasse in a flow system coupled to thermospray flame furnace atomic absorption spectrometry. Spectroscopy Letters 2006; 39 1-14.

[56] Febrianto J., Kosasih A. N., Sunarso J., Ju. Y., Indraswati N., Ismadji S. Equilibrium and kinetic studies in adsorption of heavy metals using biosorbent: A summary of recent studies. Journal of Hazardous Materials 2009; 162, 616-45.

[57] Kumar KV, Sivanesan S. Pseudo-second-order kinetic models for safranin onto rice husk: comparison of linear and non-linear regression analysis. Process Biochemistry 2006; 41 1198-1202.

[58] Savic JZ, Vasic VM. Thermodynamics and kinetics of 1,8-dihydroxy-2-(imidazol-5-ylazo)-naphthalene-3,6-disulphonic acid immobilization on Dowex resin, Colloids and Surfaces A. Physicochemical and Engineering Aspects 2006; 278 197-203.

[59] Zhao G, Wu X, Tan X, Wang X. Sorption of Heavy Metal Ions from Aqueous Solutions: A Review. The Open Colloid Science Journal 2011; 4 19-31.

[60] Li X, Zheng W, Wang D, Yang Q, Cao J, Yue X, Shen T, Zeng G. Removal of Pb (II) from aqueous solutions by adsorption onto modified areca waste: Kinetic and thermodynamic studies. Desalination 2010; 258 148-53.

[61] Bark N, Abdennouri M, Boussaoud A, Makhfouk MEL. Biosorption characteristics of Cadmium (II) onto Scolymus hispanicus L. as low-cost natural biosorbent. Desalination 2010; 258(1-3) 66-71.

[62] Lalhruaitluanga H, Jayaram K, Prasad MNV, Kumar KK. Lead(II) adsorption from aqueous solutions by raw and activated charcoals of Melocanna baccifera Roxburgh (bamboo)-A comparative study. Journal of Hazardous Materials 2010; 75 311-8.

[63] Vijayaraghavan K, Palanivelu K, Velan M. Biosorption of copper(II) and cobalt(II) from aqueous solutions by crab shell particles, Bioresource Technology 2006; 97 1411-19. 
[64] Ding Y, Jing D, Gong H, Zhou L, Yang X. Biosorption of aquatic cadmium(II) by unmodified rice straw. Bioresource Technology 2012; 114 20-5.

[65] Yaneva Z, Koumanova B, Georgieva N. Study of the Mechanism of nitrophenols sorptions on expanded perlite - Equilibrium and Kinetics Modeling. Macedonian Journal of Chemistry and Chemical Engineering 2012; 31(1) 101-14.

[66] Baidas S, Gao B, Meng X. Perchlorate removal by quaternary amine modified reed. Journal of Hazardous Materials 2011; 189 54-61.

[67] Bilgili MS. Adsorption of 4-chlorophenol from aqueous solutions by xad-4 resin: isotherm, kinetic, and thermodynamic analysis. Journal of Hazardous Materials 2006; 137 157-64.

[68] Farooq U, Kozinski JA, Khan MA, Athar M. Biosorption of heavy metals ions using wheat based biosorbents - A review of the recent literature. Bioresource Technology 2010; 101 5043-53.

[69] Gueu S, Yao B, Adouby K, Ado G. Kinetics and thermodynamics study of lead adsorption on to activated carbons from coconut and seed hull of the palm tree. International Journal Science Technology 2007; 4(1) 11-17.

[70] Zhu HY, Fu YQ, Jiang R, Jiang JH, Xiao L, Zeng GM, Zhao SL, Wang Y. Adsorption removal of congo red on magnetic cellulose/Fe3O4/activated carbon composite: Equilibrium, kinetic and thermodynamic studies. Chemical Engineering Journal 2011; 173 494-502.

[71] Bhat V, Rao P, Patil Y. Development of an integrated model to recover precious metals from electronic scrap - A novel strategy for e-waste management. Procedia - Social and Behavioral Sciences 2012; 37: 397-406.

[72] Patil YB. Development of an innovative low-cost industrial waste treatment technology for resource conservation - A case study with gold-cyanide emanated from SMEs. Procedia- Social and Behavioral Sciences 2012; 37: 379-388.

[73] Gaddi SS, Patil YB. Screening of some low-cost waste biomaterials for the sorption of silver-cyanide [ $\mathrm{Ag}(\mathrm{CN}) 2-]$ from aqueous solutions. International Journal of Chemical Sciences 2011; 9: 1063-1072.

[74] Patil YB, Paknikar KM. Biological detoxification of nickel-cyanide from industrial effluents. Process Metallurgy 2001; 11: 391-400.

[75] Patil YB, Paknikar KM. Development of a process for biodetoxification of metal cyanides from wastewaters. Process Biochemistry 2000; 35: 1139-1151.

[76] Patil YB, Paknikar KM. Biodetoxification of silver-cyanide from electroplating industry wastewater. Letters in Applied Microbiology 2000; 30: 33-37.

[77] Patil YB, Paknikar KM. Removal and recovery of metal cyanides using a combination of biosorption and biodegradation processes. Biotechnology Letters 1999; 21: 913-919. 
